\title{
A clinico-immunological study of ulcerative colitis and ulcerative proctitis
}

\author{
ANNE HARDY SMITH AND IAN W. MACPHEE \\ From the Department of Surgery, University of Liverpool
}

SUMMARY Fifteen patients with ulcerative colitis and 11 patients with ulcerative proctitis have been observed and studied for periods ranging from one to 15 years. It is suggested that the clinical course of the two disorders is quite distinct. Further, while the serum immunoglobulins were within normal limits in ulcerative proctitis, significant increases in the serum $\alpha_{2^{-}}, \beta$-, and $\gamma$-globulins and in the IgA and IgG concentrations were found in ulcerative colitis. Despite total colectomy for ulcerative colitis, the serum IgG and $\operatorname{IgA}$ concentration remained high and even after subsequent rectal resection the relative $\operatorname{IgA}$ concentration continued to increase. The significance of these findings is discussed.

Bloody diarrhoea without systemic disturbance and with mucosal changes confined to the rectum may not progress to frank ulcerative colitis. Haemorrhagic or ulcerative proctitis can, we believe, be differentiated from ulcerative colitis, even in its milder forms, on clinical and serological grounds. Autoimmune factors may be involved in the aetiology of ulcerative colitis but the results from tests in vitro for serum antibodies against alimentary antigens have been inconclusive (Polcak and Vokurka, 1960; Edgar, 1961; Gray, Walker, and Thompson, 1961; Henriksen, Gundersen, and Opsal, 1962; Soergel and Ingelfinger, 1964; Broberger, 1964; Harrison, 1965; Lagercrantz, Hammarstrom, Perlmann, and Gustafsson, 1966; Wright and Truelove, 1966; McGiven, Ghose, and Nairn, 1967).

The serum proteins and immunoglobulins were investigated in patients suffering from ulcerative colitis and ulcerative proctitis, and the clinical course of each of these conditions has been compared and contrasted.

\section{Clinical Description and Methods}

Fifteen patients with ulcerative colitis and 11 patients with ulcerative proctitis were studied.

\section{ULCERATIVE COLITIS}

The diagnosis of ulcerative colitis was made from the typical history, radiological examination by Received for publication 22 September 1970. barium enema, sigmoidoscopy, and biopsy. The average age of the patients at the beginning of the study was 35 years (range 17 to 64) and the ratio of males to females was 6 to 9 . The samples from patients with ulcerative colitis were subdivided into three groups (Table I).

Four patients whose symptoms were not thought severe enough to warrant surgery were placed in group A. They were treated at various times with salazopyrine and also with corticosteroids.

In three patients the immunoglobulins were studied just before total colectomy, in two just before and within a few weeks of operation, and in one patient three weeks after total colectomy (group B). Two of these patients were also studied after resection of the rectum, an operation carried out after resection of the colon.

A further five patients, all of whom had had total colonic resection carried out some years before, were studied from 16 months to 12 years after a subsequent resection of the rectum (group C). We can therefore assume that all active disease in the rectum and the colon had been removed in this group.

\section{ULCERATIVE PROCTITIS}

The diagnosis of ulcerative proctitis was based on normal barium enema appearances and the presence of multiple small superficial ulcers in the rectum, or on the basis of hyperaemia, a friable rectal mucosa which bled readily on examination, 


\begin{tabular}{lllll}
\hline Group & No. of Patients & Drug Therapy & Time of Investigation in Relation to Surgery & Comments \\
\hline A & 4 & $\begin{array}{l}\text { Salazopyrine and cortical } \\
\text { steroids } \\
\text { Salazopyrine and cortical } \\
\text { steroids }\end{array}$ & $\begin{array}{l}\text { No surgery } \\
\text { (a) Before colectomy (3 patients) } \\
\text { (b) Before and within a few weeks of total } \\
\text { colectomy (2) } \\
\text { (c) Three weeks after total colectomy (1) } \\
\text { Two patients were also studied after rectal } \\
\text { resection. } \\
\text { Sixteen months to 12 years after rectal } \\
\text { resection following total colectomy }\end{array}$ \\
C & 6 & None & $\begin{array}{l}\text { All active disease in the colon } \\
\text { and rectum removed. }\end{array}$ \\
\hline
\end{tabular}

Table I Subdivision of the patients with ulcerative colitis

and the presence of excess mucus. The sigmoidoscopic appearances were progressively less severe at the upper end of the rectum. In all patients a biopsy of the rectal mucosa was taken and the subsequent report usually described hyperaemia and inflammatory changes in the mucosa and submucosa. The average age of the patients was 39 years (range 18 to 66 ) and the ratio of males to females was 6 to 5 . Most of these patients were treated intermittently with salazopyrine.

\section{SERUM PROTEINS AND IMMUNOGLOBULIN STUDIES}

Serum samples were collected from each of the 15 patients with ulcerative colitis and the current group of 11 patients with ulcerative proctitis. The total protein was measured by the copper sulphate specific gravity method (Phillips, van Slyke, Dole, Emerson, Hamilton, and Archibald, 1943). Serum proteins were determined by cellulose acetate electrophoresis (Kohn and Feinberg, 1965). The concentrations of the serum immunoglobulins$\operatorname{IgA}$, IgM, and IgG-were measured using Hyland Immunoplates.

Tissue antigens were prepared from samples of human large and small intestine removed at sigmoidoscopy, colectomy, or at necropsy, and from fresh rat large and small intestine. Samples of rectal or colonic mucosa were obtained from five of the patients with ulcerative colitis and five of the patients with ulcerative proctitis. The human tissue samples were sometimes stored at $-15^{\circ} \mathrm{C}$ before extraction. The initial extraction procedure was a modification of the methods used by Gajdusek (1958) and Webster (1965) using normal saline. The tissue residue was then reextracted with Analar phenol at $65^{\circ} \mathrm{C}$ by the method of Westphall, Luderitz, and Bister as used by Broberger and Perlmann (1959). The electroimmunoprecipitation test was carried out as described by Webster (1965). Immunoelectrophoresis was carried out using the transfer method described by Kohn (1957, 1960, and 1966).

\section{Results}

\section{CLINICAL STUDIES}

\section{Ulcerative colitis}

In seven patients, the rectum was resected up to 12 years after total colectomy. In most a recrudescence of disease in the rectum occurred, as judged by the periodic discharge of blood and mucus from the rectum. Proctoscopy at the time revealed that the mucosa of the rectum was friable, bled easily, and occasionally ulcers were observed. In one patient in particular (no. 38) these bouts occurred in association with recurrence of iridocyclitis, skin rashes, joint pains, and swelling of the hands and feet, increased pain from ankylosing spondulitis, and activity of a duodenal ulcer. It is interesting to note that in the two years since resection of the rectum he still complains from time to time of these associated manifestations.

\section{Ulcerative proctitis}

With or without treatment by salazopyrine, complete resolution of the condition took place in the 11 patients in this series. In the patients receiving salazopyrine, blood and mucus disappeared from the stool while the rectal mucosa remained friable and readily bled on sigmoidoscopy.

In every case, the appearance of the rectum to $20 \mathrm{~cm}$ and beyond became normal and there has been no subsequent relapse up to a maximum of 14 years in the present series.

\section{SERUM PROTEIN AND IMMUNOGLOBULIN STUDIES}

The experimental results are shown in Tables II and III. The patients with ulcerative colitis and ulcerative proctitis had similar age distributions, and the difference in their results cannot be attributed to a difference in the age of the patients.

Serum protein concentrations were expressed 


\begin{tabular}{|c|c|c|c|c|c|c|c|}
\hline \multirow[t]{2}{*}{ No. of Patients } & \multirow[t]{2}{*}{ Male } & \multirow[t]{2}{*}{ Female } & \multirow{2}{*}{$\begin{array}{l}\text { Mean of Age Group } \\
( \pm S D)\end{array}$} & \multicolumn{4}{|c|}{ Mean Serum Concentration $( \pm S D)$} \\
\hline & & & & $\begin{array}{l}\text { Total Protein } \\
(\mathrm{g} / 100 \mathrm{ml})\end{array}$ & $\begin{array}{l}\text { Albumin } \\
(\mathrm{g} / 100 \mathrm{ml})\end{array}$ & $\begin{array}{l}\alpha_{1}-\text { Globulin } \\
(\mathrm{g} / 100 \mathrm{ml})\end{array}$ & $\begin{array}{l}\alpha_{2}-\text { Globulin } \\
(\mathrm{g} / 100 \mathrm{ml})\end{array}$ \\
\hline $\begin{array}{l}\text { Ulcerative colitis } \\
15\end{array}$ & 6 & 9 & $35 \cdot 3 \pm 14 \cdot 2$ & $6.7 \pm 0.6$ & $4 \cdot 1 \pm 0 \cdot 7$ & $0.2 \pm 0.1$ & $0.7 \pm 0.2$ \\
\hline $\begin{array}{l}\text { Ulcerative proctitis } \\
11\end{array}$ & 6 & 5 & $39 \cdot 2 \pm 17 \cdot 0$ & $6.1 \pm 0.5$ & $4 \cdot 2 \pm 0 \cdot 7$ & $0.2 \pm 0.1$ & $0.5 \pm 0.1$ \\
\hline $\begin{array}{l}\text { Controls } \\
37\end{array}$ & 17 & 20 & $37 \cdot 2 \pm 17 \cdot 3$ & $6.7 \pm 0.5$ & $4.6 \pm 0.4$ & $0.2 \pm 0.1$ & $0.6 \pm 0.1$ \\
\hline
\end{tabular}

Table II Mean serum concentration in patients with ulcerative colitis, ulcerative proctitis, and in the controls

as $\mathrm{g} / 100 \mathrm{ml}$ serum and serum immunoglobulin concentrations as $\mathrm{mg} / 100 \mathrm{ml}$ serum. In addition the immunoglobulin concentrations were expressed as a percentage of the total immunoglobulin concentration (IgA + IgM + IgG) to show changes in their concentrations relative to overall changes in the total immunoglobulin concentration.

Where several samples had been obtained from one patient, a single sample was selected using random numbers, and results from this sample were used to calculate the mean values for the various groups of patients. The mean values from the ulcerative colitis patients were compared with those from the ulcerative proctitis patients (Tables II and III). In addition the mean values from groups $\mathrm{A}, \mathrm{B}$, and $\mathrm{C}$ of the ulcerative colitis patients were collated. Although the groups are small and the divisions somewhat arbitrary, the results from the three groups show some interesting trends.

Total protein and albumin

The group of patients with ulcerative proctitis had a lower total protein concentration than either the group of ulcerative colitis patients or the controls (Table III). The ulcerative colitis patients in groups A and B had lower total protein concentrations than those in group C (Fig. 1). The albumin concentrations of both the ulcerative colitis patients and the ulcerative proctitis patients were significantly below that of the controls. The ulcerative colitis patients in group $\mathrm{C}$ had a mean albumin concentration which was significantly higher than that of the ulcerative colitis patients in groups A and B. The patients in group B had an even lower mean but a wider scatter.

\section{a-Globulins}

There were no significant differences between the mean concentrations of $a_{1}$-globulin in the various groups of patients and the controls (Table III). The mean concentration of $a_{2}$-globulin for the group of ulcerative colitis patients was significantly greater than that of either the controls or the patients with ulcerative proctitis (Table III). The ulcerative colitis patients in group B had a much higher concentration of $a_{2}$-globulin than either

\begin{tabular}{|c|c|c|c|c|c|c|}
\hline & \multicolumn{2}{|c|}{$\begin{array}{l}\text { Ulcerative Colitis and } \\
\text { Ulcerative Proctitis }\end{array}$} & \multicolumn{2}{|c|}{$\begin{array}{l}\text { Ulcerative Colitis and } \\
\text { Controls }\end{array}$} & \multicolumn{2}{|c|}{$\begin{array}{l}\text { Ulcerative Proctitis and } \\
\text { Controls }\end{array}$} \\
\hline & $\begin{array}{l}\text { Difference } \\
\text { between Means }\end{array}$ & $\boldsymbol{P}$ & $\begin{array}{l}\text { Difference } \\
\text { between Means }\end{array}$ & $\boldsymbol{P}$ & $\begin{array}{l}\text { Difference } \\
\text { between Means }\end{array}$ & $\boldsymbol{P}$ \\
\hline Total protein $(\mathrm{g} / 100 \mathrm{ml})$ & 0.6 & 0.005 & 0 & - & -0.6 & 0.005 \\
\hline Albumin $(\mathrm{g} / 100 \mathrm{ml})$ & $-0 \cdot 1$ & $0 \cdot 2$ & -0.05 & 0.001 & -0.4 & 0.02 \\
\hline$a_{1}$-Globulin $(\mathrm{g} / 100 \mathrm{ml})$ & 0 & - & 0 & - & 0 & $\overline{-}$ \\
\hline$a_{2}$-Globulin $(\mathrm{g} / 100 \mathrm{ml})$ & 0.2 & 0.005 & 0.1 & 0.001 & -0.1 & $0 \cdot 2$ \\
\hline$\beta$-Globulin $(\mathrm{g} / 100 \mathrm{ml})$ & $0 \cdot 2$ & 0.005 & $\mathbf{0} \cdot \mathbf{2}$ & 0.001 & 0 & - \\
\hline$\gamma$-Globulin $(\mathrm{g} / 100 \mathrm{ml})$ & $0 \cdot \overline{3}$ & 0.005 & $0 \cdot 2$ & 0.05 & $-0 \cdot 1$ & $0 \cdot 3$ \\
\hline $\mathrm{IgA}(\mathrm{mg} / 100 \mathrm{ml})$ & 223 & 0.02 & 156 & 0.02 & -67 & $\mathbf{0} \cdot \mathbf{3}$ \\
\hline IgA (\% total Ig) & $4 \cdot 6$ & 0.05 & $2 \cdot 4$ & $0 \cdot 2$ & $-2 \cdot 2$ & $0 \cdot 3$ \\
\hline IgM (mg/100 ml) & 4 & 0.90 & 7 & 0.7 & 3 & 0.9 \\
\hline IgM ( $\%$ total Ig) & -0.9 & 0.3 & -0.8 & 0.2 & $0 \cdot 1$ & 0.9 \\
\hline IgG $(\mathrm{mg} / 100 \mathrm{ml})$ & 436 & 0.05 & 421 & 0.02 & -15 & 0.95 \\
\hline IgG ( $\%$ total Ig) & $-3 \cdot 6$ & 0.2 & $-1 \cdot 7$ & 0.4 & 1.9 & 0.4 \\
\hline
\end{tabular}

Table III The difference between the mean serum protein and immunoglobin concentrations in patients with ulcerative colitis, ulcerative proctitis, and in controls 


\begin{tabular}{|c|c|c|c|c|c|c|c|}
\hline \multirow{2}{*}{$\begin{array}{l}\beta \text {-Globulin } \\
(\mathrm{g} / 100 \mathrm{ml})\end{array}$} & \multirow{2}{*}{$\begin{array}{l}\gamma \text {-Globulin } \\
(\mathrm{g} / 100 \mathrm{ml})\end{array}$} & \multicolumn{2}{|l|}{$\operatorname{IgA}$} & \multicolumn{2}{|l|}{$I g M$} & \multicolumn{2}{|l|}{$I g G$} \\
\hline & & $\mathrm{Mg} / 100 \mathrm{ml}$ & $\%$ Total Ig & $M g / 100 \mathrm{ml}$ & $\%$ Total Ig & $\mathrm{Mg} / 100 \mathrm{ml}$ & $\%$ Total Ig \\
\hline $0.8 \pm 0.1$ & $0.9 \pm 0.2$ & $460 \pm 251$ & $14.5 \pm 5.6$ & $115 \pm 73$ & $3.8 \pm 2.0$ & $2,435 \pm 537$ & $81 \cdot 7 \pm 6.0$ \\
\hline $0.6 \pm 0.1$ & $0.6 \pm 0.2$ & $237 \pm 157$ & $9 \cdot 9 \pm 5 \cdot 1$ & $111 \pm 40$ & $4 \cdot 7 \pm 1 \cdot 5$ & $1,999 \pm 435$ & $85.3 \pm 5.9$ \\
\hline $0.6 \pm 0.1$ & $0.7 \pm 0.3$ & $304 \pm 185$ & $12 \cdot 1 \pm 5 \cdot 6$ & $108 \pm 48$ & $4.6 \pm 1.8$ & $2,014 \pm 564$ & $83.4 \pm 6.2$ \\
\hline
\end{tabular}

Table II continued

the patients in groups $\mathbf{A}$ or $\mathbf{C}$. The latter group had the lowest $a_{2}$-globulin concentrations of the whole ulcerative colitis group (Fig. 1).

\section{$\beta$-Globulin}

The mean $\beta$-globulin concentration of the ulcerative colitis patients was significantly greater than that of either the controls or the patients with ulcerative proctitis (Table III). The ulcerative colitis patients in group $\mathrm{C}$ had the highest $\beta$-globulin concentrations, while those in group $\mathrm{B}$ had the lowest concentrations of $\beta$-globulin (Fig. 1).

\section{$\gamma$-Globulin}

The mean absolute serum $\gamma$-globulin $(\mathrm{g} / 100 \mathrm{ml})$ for the 15 patients with ulcerative colitis was significantly greater than the corresponding means for both the 11 patients with ulcerative proctitis $(P=0.005)$ and for the 37 controls $(P=0.05)$ (Table III). The difference between the patients with ulcerative proctitis and the controls was not significant. The ulcerative colitis patients in group $B$ had the highest $\gamma$-globulin concentrations, while those in group B had the lowest concentrations of $\gamma$-globulin (Fig. 1). However, the differences were not significant because of the wide scatter of results about the three means.

\section{Immunoglobulin $A$}

The immunoglobulin concentrations were determined independently of the $\gamma$-globulin by quantitative immunodiffusion. The mean absolute serum IgA concentration $(\mathrm{mg} / 100 \mathrm{ml})$ for the 15 patients with ulcerative colitis was significantly greater than the corresponding means for 11

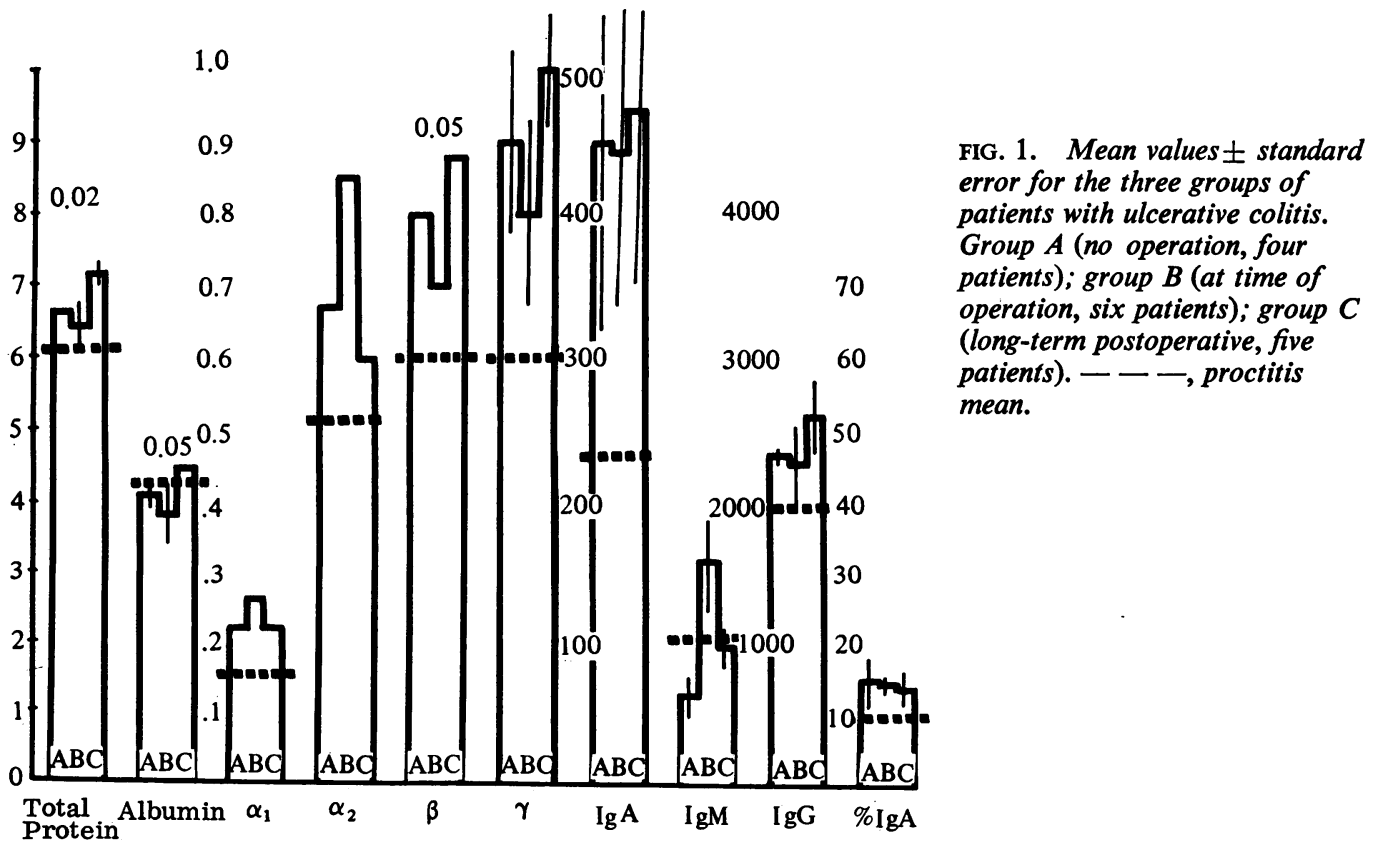


patients with ulcerative proctitis $(P=0.02)$ and for 37 controls $(P=0.02)$ (Table III). The difference between the patients with ulcerative proctitis and the controls was not significant. The mean relative serum $\operatorname{IgA}$ concentration $(\%$ total Ig) for the ulcerative colitis patients was significantly greater $(P=0.05)$ than that for patients with ulcerative proctitis (Table III). There were no significant differences between either the absolute or relative concentrations of IgA for the three groups of patients with ulcerative colitis (Fig. 1).

\section{Immunoglobulin $M$}

The mean absolute and relative concentrations of IgM for both ulcerative colitis patients and ulcerative proctitis patients were within normal limits. The patients with ulcerative colitis in group B had higher absolute and relative concentrations of IgM than the other ulcerative colitis patients.

\section{Immunoglobulin $G$}

The mean absolute serum IgG concentration $(\mathrm{mg} / 100 \mathrm{ml})$ for the 15 patients with ulcerative colitis was significantly greater than the corresponding means for both 11 patients with ulcerative proctitis $(P=0.05)$ and 37 controls $(P=0.02)$ (Table III). The difference between the patients with ulcerative proctitis and the controls was not significant. There were no significant differences between the mean relative IgG concentrations of the ulcerative colitis and ulcerative proctitis patients or the controls (Table III). Nor were there significant differences between either the absolute or relative IgG concentrations for the three ulcerative colitis groups (Fig. 1).

\section{SERIAL DETERMINATIONS}

Serial determinations of the serum $\gamma$-globulin and immunoglobulin concentrations were carried out in three of the patients with ulcerative colitis (nos. 38, 93, and 131) and in two of the patients with ulcerative proctitis (nos. 63 and 178). Results from one ulcerative colitis patient (no. 38) are shown in Figure 2. The two patients with ulcer-

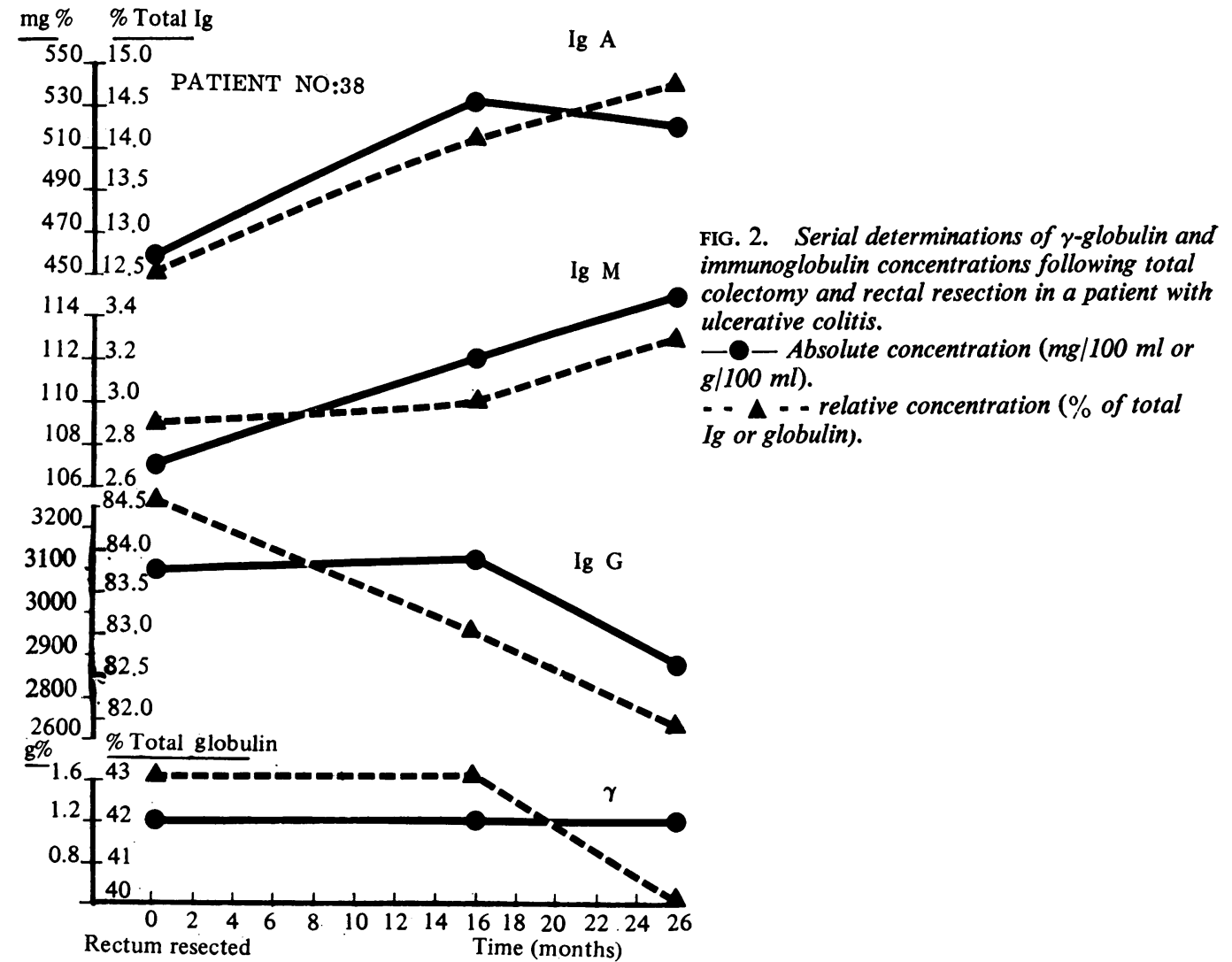


ative proctitis did not show any consistent change in the serum $\gamma$-globulin or immunoglobulin concentrations during the period of investigation. Two of the patients with ulcerative colitis were investigated after colectomy but before rectal resection. These patients and the third were subsequently studied following rectal resection. The immunoglobulin concentrations showed considerable variations in each patient, and it was difficult to relate changes to colectomy or rectal resection. After colectomy the IgG concentrations appeared to increase, while after rectal resection the absolute IgG concentration decreased in two of the three patients. Although the absolute concentration of IgG tended to decrease after rectal resection, the relative IgA concentration increased in all three patients following rectal resection, and was unchanged in the third two years after operation.

IMMUNOELECTROPHORESIS AND

IMMUNOELECTROPHORECTIOPRECIPITATION USING TISSUE ANTIGENS

No positive reactions were demonstrated when sera from patients with ulcerative colitis or ulcerative proctitis were tested against phenolic or saline extracts of autologous, homologous, or heterologous human or rat, intestine, colon, or rectum.

\section{Discussion}

In this series, the patients with ulcerative colitis showed significant increases in the serum $\alpha_{2}, \beta$, and $\gamma$-globulin concentrations accompanied by similar increases in the IgA and IgG concentrations. The serum globulin and immunoglobulin concentrations of the patients with ulcerative proctitis were within normal limits.

Previous reports in the literature have suggested that autoimmune phenomena are involved in the aetiology of ulcerative colitis but the results from tests in vitro for serum antibodies against alimentary antigens have been inconclusive (Polcak and Vokurka, 1960; Edgar, 1961; Gray et al, 1961; Henriksen et al, 1962; Soergel and Ingelfinger, 1964; Broberger, 1964; Harrison, 1965; Lagercrantz et al, 1966; Wright and Truelove, 1966; McGiven et al, 1967).

Bjørneboe (1943) demonstrated the considerable increase in the serum globulin concentration following immunization with polyvalent pneumococcus and salmonella vaccines. Immunoglobulins have already been associated with specific autoimmune factors, eg, reagins, rheumatoid factor, and LE factor (Heremans, Vaerman,
Carbonara, Rodhain, and Heremans, 1963; Mackay and Burnet, 1963; Glynn and Holborow, 1965). In the present study measurement of the concentrations of the three major immunoglobulins, IgA, IgM, and IgG, was used as a measure of increased immunological activity.

Since IgA predominates in the plasma cells of normal human intestinal mucosa (Crabbé, Carbonara, and Heremans, 1965; Crabbé and Heremans, 1966; Gelzayd, Kraft, and Fitch, 1967) a study of serum IgA concentrations was of particular interest in the present investigation. The presence of a consistently increased serum immunoglobulin concentration in patients with ulcerative colitis would provide further evidence of immunological disorder in this disease and would also be of potential diagnostic value. If changes in the serum immunoglobulin concentrations were directly related to the clinical severity or time course of the disease, this would suggest a direct relationship between the increased immunological activity and the development of clinical signs and symptoms. The effect of surgical removal of the diseased colon on the serum immunoglobulin concentrations is also of interest.

If the inflammatory reaction in the bowel wall were to be the sole cause of the rise in serum immunoglobulins it would be natural to expect higher concentrations where the inflammatory reaction was both more extensive and more severe. Comparison of the results from the three subgroups of patients with ulcerative colitis did not show any significant differences between their immunoglobulin concentrations.

Serial studies were carried out in three patients who had undergone colectomy followed by rectal resection. If the diseased colon and rectum were the primary source of autoantigen, the concentrations of the serum immunoglobulins containing the corresponding autoantibody would be expected to return eventually to within normal limits. However, the immunoglobulin concentrations showed considerable variations in each patient, and it was difficult to relate changes to colectomy or rectal resection. After colectomy the IgG concentrations appeared to increase while after rectal resection the absolute IgG concentrations decreased in two of the three patients. Although the absolute concentration of $\operatorname{IgA}$ tended to decrease after rectal resection, the relative IgA concentration increased in all three patients.

The apparent continuation of immunological disorder despite removal of the target organ and source of organ-specific autoantigens, could be explained thus. Clones of immunoglobulin-producing cells which have already been committed 
to produce a specific autoantibody could continue antibody synthesis in the absence of the corresponding antigen. Circulating antibodies against infectious diseases are known to persist at low titres long after the removal of the original antigenic stimulus. Alternatively, the persistence of raised immunoglobulin concentrations could represent a systemic lesion of which the colitis was only one manifestation. Removal of the colon would have no effect on the fundamental systemic lesion. This view is supported by the persistence of nonspecific inflammatory changes in the eye and the joints of one patient. Further evidence for this hypothesis is the failure to demonstrate any precipitation reaction between the sera of patients with ulcerative colitis and extracts of rectal mucosa in the present study.

As we now look in retrospect at the patients with ulcerative colitis in group B, it is of interest to note that they had the highest titre of $\alpha_{2}$ globulin. These were the patients in whom it was deemed on clinical grounds that resection of the colon was necessary. It is of interest that $\mathrm{De}$ Dombal (1968) reported an increase in $a_{2}$ globulin associated with clinical relapse, which itself is an indication for surgical treatment in patients with ulcerative colitis.

The prolonged clinical study of ulcerative proctitis suggests to us that this is not ulcerative colitis in a mild form. In every instance complete resolution took place and recurrence has not developed even without recognized treatment. The serum immunoglobulins in these patients in no way differed from those of normal controls. We would agree that the apparent inflammatory change in the rectum was of lesser degree than in ulcerative colitis. It could therefore be properly suggested that the immunological response might be less marked. The fact that it does not seem to have occurred suggests that the difference between the two conditions is not one of degree, an observation in keeping with the different clinical course of the two conditions. In this series the diagnosis was firmly made on the clinical findings before serum immunoglobulin data had been obtained. We suggest that an examination of the serum immunoglobulins may prove to be a useful additional test for distinguishing between ulcerative colitis and ulcerative proctitis.
References

Bjørneboe, M. (1943). Serum proteins during immunization. Acta path. microbiol. scand., 20, 221-239.

Broberger, O. (1964). Immunologic studies in ulcerative colitis. Gastroenterology, 47, 229-240.

Broberger, O., and Perlmann, P. (1959). Autoantibodies in human ulcerative colitis. J. exp. Med., 110, 657-674.

Crabbé, P. A., Carbonara, A. O., and Heremans, J. F. (1965) The normal human intestinal mucosa as a major source of plasma cells containing $\gamma \mathrm{A}$-immunoglobulin. Lab. Invest., $14,235-248$.

Crabbé, P. A., and Heremans, J. F. (1966). The distribution of immunoglobulin-containing cells along the human gastrointestinal tract. Gastroenterology, 51, 305-316.

De Dombal, F. T. (1968). Prognostic value of the serum proteins during severe attacks of ulcerative colitis. Gut, 9, 144-149.

Edgar, W. M. (1961). Specific antibody against gastro-intestinal mucosa. Lancet, 2, 109.

Gajdusek, D. C. (1958). An 'autoimmune' reaction against human tissue antigens in certain acute and chronic diseases. I. Serological investigations. Arch. intern. Med., 101, 9-29.

Gelzayd, E. A., Kraft, S. C., and Fitch, F. W. (1967). Immunoglobulin A localization in rectal mucosal epithelial cells. Science, 157, 930-931.

Glynn, L. E., and Holborow, E. J. (1965). Autoimmunity and Disease. Blackwell, Oxford.

Gray, J. G., Walker, F. C., and Thompson, D. (1961) Autoimmunity in ulcerative colitis. Lancet, 2, 51-52.

Harrison, W. J. (1965). Autoantibodies against intestinal and gastric mucous cells in ulcerative colitis. Lancet, 1, 13461350.

Henriksen, S. D., Gundersen, W. B., and Opsal, R., Jr. (1962). Attempts to demonstrate autoantibodies in colitis ulcerosa. Acta path. microbiol. scand., 55, 68-70.

Heremans, J. F., Vaerman, J. P., Carbonara, A. O., Rodhain, J. A. and Heremans, M. T. (1963). $\gamma_{1}$ A-Globulin ( $\left.\beta_{2} A-g l o b u l i n\right)$ : its isolation properties, function and pathology. Protides biol. Fluids, 10, 108-121.

Kohn, J. (1957). An immuno-electrophoretic technique. Nature (Lond.), 180, 986-987.

Kohn, J. (1960). Cellulose acetate electrophoresis and immunodiffusion techniques. In Chromatographic and Electrophoretic Techniques, vol 2. Zone Electrophoresis, pp. 56-90. Heinemann, London.

Kohn, J. (1966). Personal communication.

Kohn, J., and Feinberg, J. G. (1965). Shandon instrument applications No. 11. Electrophoresis on Cellulose Acetate, Shandon Scientific Co., Sewickley, Pennsylvania.

Lagercrantz, R., Hammarstrom, S., Perlmann, P., and Gustafsson, B. E. (1966). Immunological studies in ulcerative colitis. III. Incidence of antibodies to colon-antigen in ulcerative colitis and other gastro-intestinal diseases. Clin. exp. Immunol., 1, 263-276.

Mackay, I. R., and Burnet, F. M. (1963). Autoimmune Diseases. Pathogenesis, Chemistry and Therapy. Thomas, Springfield, IIl.

McGiven, A. R., Ghose, T., and Nairn, R. C. (1967). Autoantibodies in ulcerative colitis. Brit. med. J., 2, 19-23.

Phillips, R. A., Van Slyke, D. D., Dole, V. P., Emerson, K., Jr., Hamilton, P. B., and Archibald, R. M. (1943). The copper sulfate method for measuring specific gravities of whole blood and plasma. Bull. U.S. Army med. Dep., 71, 66-83.

Polcak, J., and Vokurka, V. (1960). Auto-immune reactions in the course of ulcerative colitis. Amer. J. dig. Dis., 5, 395-405.

Soergel, K. H., and Ingelfinger, F. J. (1964). Composition of rectal mucus in normal subjects and patients with ulcerative colitis. Gastroenterology, 47, 610-616.

Webster, J. E. (1965). The detection of thyroid antibodies by immunoelectrophoresis. J. med. Lab. Technol., 22, 10-11.

Wright, R., and Truelove, S. C. (1966). Auto-immune reactions in ulcerative colitis. Gut, 7, 32-40. 